\title{
UDC 514.18
}

\section{MAPLE- MODELS OF MOTION OF A PARTICLE IN A PLANE THAT PERFORMS RECIPROCATING OSCILLATIONS}

\author{
A.V. Nesvidomin, PhD \\ National University of Life and Environmental Sciences of Ukraine \\ E-mail: a.nesvidomin@gmail.com
}

\begin{abstract}
The purpose of the study is the development of Maple-model of motion of a particle on a sloping plane, which performs reciprocating oscillations.

A computational experiment was conducted to study the trajectory-kinematic properties of the motion of a particle on a sloping plane, which performs reciprocating oscillations.

It is shown that for a horizontal rough plane, which performs reciprocating oscillation displacements, the absolute and relative trajectories of the particle are most rapidly stabilized by the largest coefficient of friction. Particles with a lower coefficient of friction have a smaller amplitude of absolute trajectory. The initial velocity and direction of throwing influence the time and place of the stabilization of the movement.
\end{abstract}

Key words: accompanying triedrone, material point, inclined plane, trajectory of motion

Topicality. In many technological processes of agricultural production there is a movement of material particles on an inclined plane that performs reciprocating oscillations. Knowledge of the patterns of motion of a particle (as a material point) by a rough plane in three-dimensional space allows us to calculate the structural and kinematic parameters of the working bodies.

Analysis of recent research and publications. An analytical derivation of the motion of a particle on a sloping plane that performs reciprocating oscillations is reduced to the compilation of a system of differential equations of the second order, the dependence of which is the trajectory of the particle, its velocity, acceleration, the length of the traversed path, the force of the normal reaction, the time of movement to it stops and other trajectory-kinematic characteristics. The sequence of analytic 
transformations and methods for solving the derivation of a system of differential equations is quite labor-intensive.

Computer modeling of motion of a particle on a sloping plane, which performs reciprocating oscillations, allows to discard bulky analytical transformations carried out by a scientist and provide him with a convenient dialogue mode for performing necessary computational experiments on particle motion analysis under different initial conditions of its throwing [1].

The purpose of the study is the development of Mapple-a model of motion of a particle on a sloping plane, which performs reciprocating oscillations.

Materials and methods of research. Listing the maple model PlaneOxaMove_t of studing of the motion of a particle on a rough slope plane $R[u \cos (\xi), v \sin (\xi), 0]$, which carries out different translational displacements in space, is presented on the site geometry.com.ua..

Let us dwell only on its vibrational displacement along the axis $O x$ :

$$
\boldsymbol{M}=\boldsymbol{M}[l \sin (v t), 0,0],
$$

where: $v_{s} l$ - velocity and amplitude of oscillations.

In the projections on the orts $u$ and $v$ of triedrone $O u v N[2,3]$ we obtain the following system of differential equations of the particle motion law in an inclined plane:

$$
\left\{\begin{array}{c}
O u:=m\left(-l \sin (v t) v^{2}+\frac{d^{2}}{d t^{2}} u(t)\right)=-\frac{f m g \frac{d}{d t} u(t) \sin (\xi)}{\sqrt{\left(\frac{d}{d t} u(t)\right)^{2}+\left(\frac{d}{d t} v(t)\right)^{2}}} \\
O v:=m \frac{d^{2}}{d t^{2}} v(t)=-\frac{m g\left(f \frac{d}{d t} v(t) \sin (\xi)+\cos (\xi) \sqrt{\left(\frac{d}{d t} u(t)\right)^{2}+\left(\frac{d}{d t} v(t)\right)^{2}}\right)}{\sqrt{\left(\frac{d}{d t} u(t)\right)^{2}+\left(\frac{d}{d t} v(t)\right)^{2}}}
\end{array}\right.
$$

Research results and their discussion. In fig. 1 an absoluter $(t)$, relative $\rho(t)$ of the trajectory of the particle, the graphs of its absolute $V(t)$ and the relative velocity 
$V_{\rho}(t)$ are constructed, depending on the angle of the casting of the particle $\alpha_{o}=-90^{\circ}, 45^{\circ}, 0^{\circ}, 45^{\circ}$ under conditions : the slope of the plane at an angle $\xi=75^{\circ}$ from the vertical position; fluctuation velocity $v=0.5 \mathrm{c}^{-1}$; amplitude of oscillation $l=2$; coefficient of friction $f=0.3$; initial velocity $V_{o}=4$. Direction of graphs of relative velocities to zero (Fig. 1, d) suggests that all particles, regardless of the direction of the throw $\alpha_{o}$ stop in a sloping plane at different intervals of time - cease to slip in it. This will happen if $f g>l v^{2}$.

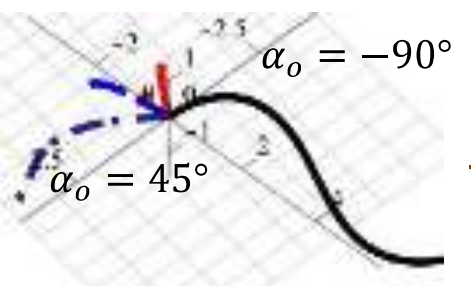

a)

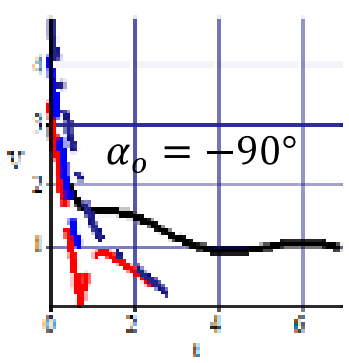

b)

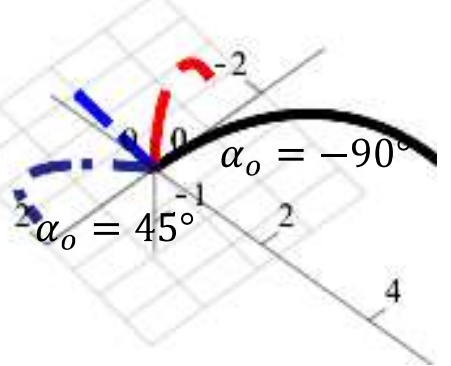

c)

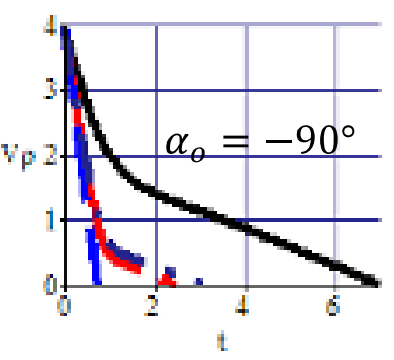

d)

Fig. 1. The trajectories $r(t), \rho(t)$ and graphs of velocities $V(t), V_{\rho}(t)$ of the particle depending on the angle of throwing $\alpha_{o}$

Let the oscillation velocity be equal to $v=2 \mathrm{c}^{-1}$. In this case, the particles do not stop zigzag sliding down the sloping plane. Note that the motion of the particle has almost stabilized in the interval $t \approx 4$ the graphs of absolute $V(t)$ and relative $V_{\rho}(t)$ velocities coincide (Fig. 2).

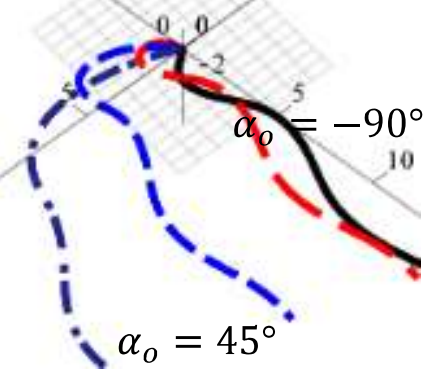

a)

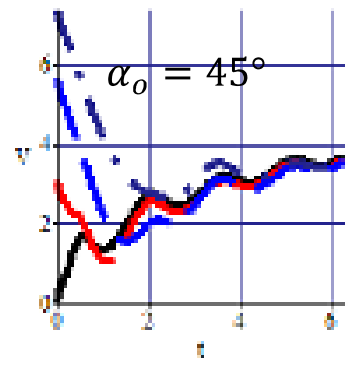

b)

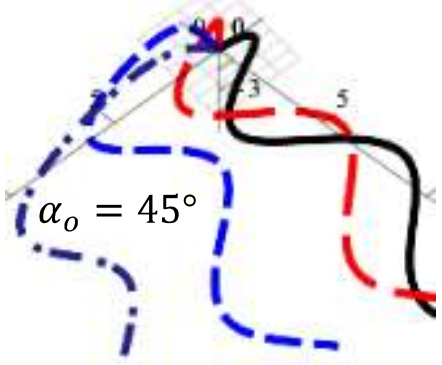

c)

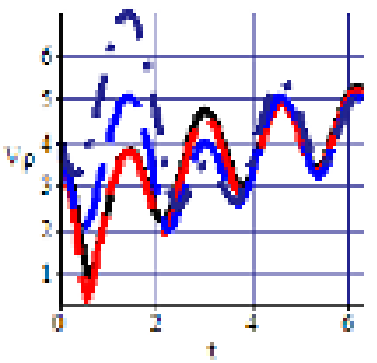

d)

Fig. 2. Trajectories $r(t), \rho(t)$ and graphs of velocities $V(t), V_{\rho}(t)$ of the particle depending on the angle of throwing $\alpha_{o}$ 
If the particles are throwing in the same direction $\alpha_{\circ}=-45^{\circ}$ with the same initial velocity $V_{o}=8$, but with different friction coefficient $f=0.01,0.15,03,0.45$, then particles with a lower coefficient of friction $f$ slide down the plane faster and have a less zigzag trajectory (Fig. 3).

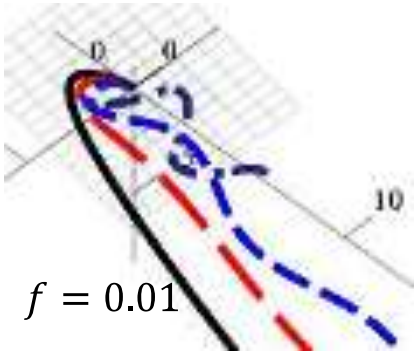

a)

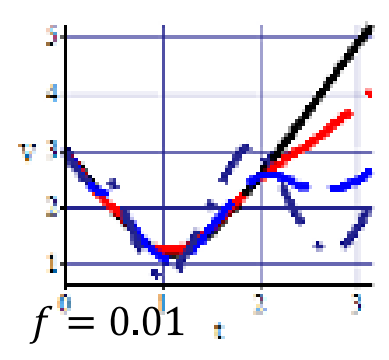

b)

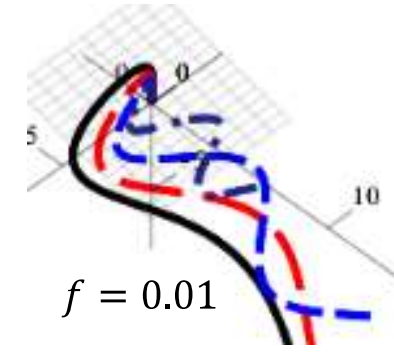

c)

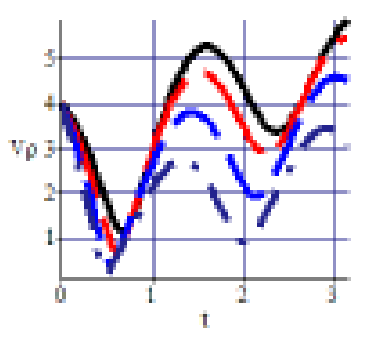

d)

Fig. 3. The trajectories $r(t), \rho(t)$ and the graphs $V(t), V_{\rho}(t)$ of the particle of the dependence $f$

From particles abandoned in one direction $\alpha_{o}=-45^{\circ}$ with a coefficient of friction $f=0.3$, but with different initial velocities $V_{o}=1,2,4,8$, the particles with the smallest initial velocity will come forward the fastest way to stabilize the movement: $t \approx 2$ when $V_{o}=2$ and $t \approx 6$ when $V_{o}=8$ ( Fig. 4).

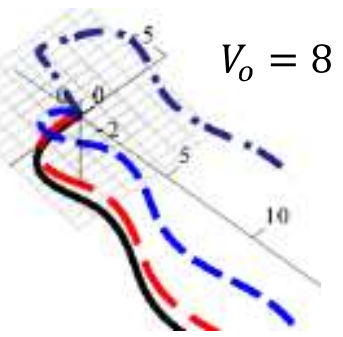

a)

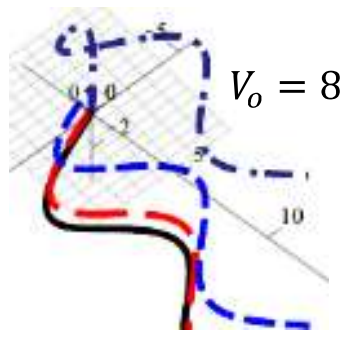

b)

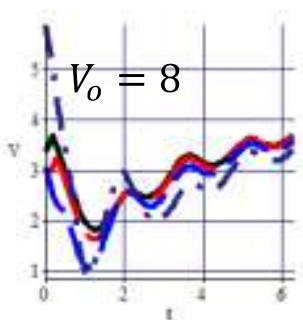

c)

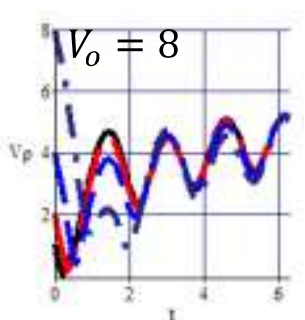

d)

Fig. 4. The trajectories $r(t), \rho(t)$ and the graphs $V(t), V_{\rho}(t)$ of the particle in the dependence $V_{o}$

\section{Conclusions and perspectives.}

1. The possibilities of the developed method of computer simulation of the motion of a particle on the investigation of the trajectory-kinematic properties of the motion of a particle on an inclined plane, which performs reciprocating oscillations, are confirmed. 
2. The peculiarities of analytical calculations in the formation of the laws of motion of a particle in projections on the otters of the accompanying triedrone OuvN and $\boldsymbol{O T P N}$ are given, with the choice of an independent time parameter $t$, position $u$, and direction $a$.

3. A complex of computational experiments was conducted to study the trajectory-kinematic properties of the motion of a particle from the study of trajectorykinematic properties of the motion of a particle on an inclined plane, which performs reciprocating oscillations under initial conditions: position of a plane, place $\left[u_{o}, v_{o}\right]$ and direction $\alpha_{o}$ of the particle, its initial velocity $V_{o}$ and friction coefficient $f$.

4. It is shown that for a horizontal rough plane, which performs reciprocation oscillations, the absolute and relative trajectories of the particle are most rapidly stabilized at the highest friction coefficient. Particles with a lower coefficient of friction have a smaller amplitude of absolute trajectory. The initial velocity and direction of throwing influence the time and place of the stabilization of the movement.

5. The angle of inclination of the rough vibrational plane greatly affects the form of the absolute and relative particle trajectory after stabilizing their displacementthey are zigzag-shaped, whose amplitude depends on the oscillation parameters.

\section{List of references}

1.Несвідомін А.В. Моделювання руху частинки по шорсткій горизонтальній площині, яка здійснює прямолінійні коливальні переміщення / А.В. Несвідомін // Сучасні проблеми моделювання: зб. наук праць МДПУ ім. Б. Хмельницького. - Мелітополь: МДПУ, 2015. - Вип.4. - С.100-104.

2.Пилипака С.Ф. Кінематична інтерпретація руху супровідних тригранників Френе і Дарбу через внутрішні параметри кривих /С.Ф. Пилипака // Науковий вісник НАУ. - К.: НАУ, 1998. -Вип.4. -С.143-146.

3. Пилипака С.Ф. Теорія складного руху матеріальної частинки на площині. Частина перша. Абсолютна швидкість і траєкторія / /С.Ф. Пилипака // Електротехніка і механіка. - 2006. -№1. - С. 84-94. 


\section{References}

1. Nesvidomin, A. V. (2015). Modeliuvannia rukhu chastynky po shorstkii horyzontalnii ploshchyni, yaka zdiisniuie priamoliniini kolyvalni peremishchennia [Modeling of motion of a particle on a rough horizontal plane, which carries out straight-line oscillatory displacements]. Suchasni problemy modeliuvannia: zb. nauk prats MDPU im. B. Khmelnytskoho, 4,100-104.

2. Pylypaka, S. F. (1998). Kinematychna interpretatsiia rukhu suprovidnykh tryhrannykiv Frene i Darbu cherez vnutrishni parametry kryvykh [Kinematical interpretation of the motion of the accompanying Fresnel and Darboux triangles through the internal parameters of the curves]. Naukovyi visnyk NAU, 4, 143-146.

3. Pylypaka, S. F. (2006). Teoriia skladnoho rukhu materialnoi chastynky na ploshchyni. Chastyna persha. Absoliutna shvydkist i traiektoriia. [The theory of the complex motion of a particle on a plane. Part One Absolute velocity and trajectory]. Elektrotekhnika i mekhanika, 1, 84-94.

\section{МАРLЕ-МОДЕЛІ РУХУ ЧАСТИНКИ ПО ПОХИЛІЙ ПЛОЩИНІ, ЯКА ЗДІЙСНЮЄ ЗВОРОТНО-ПОСТУПАЛЬНІ КОЛИВАННЯ}

\section{А. В. Несвіоомін}

Анотація. Мета дослідження - розробка Mapple-моделі руху частинки по похилій площині, яка здійснює зворотно-поступальні коливання.

Проведений обчислювальний експеримент з дослідження траєкторнокінематичних властивостей руху частинки по похилій площині, яка здійснює зворотно-поступальні коливання.

Показано, щзо для горизонтальної шорсткої площини, яка здійснює зворотноколивальні переміщення, найшвидше стабілізують абсолютну та відносну траєкторії частинки за найбільшим коефіцієнтом тертя. Частинки з меншим коефіиієнтом тертя мають меншу амплітуду абсолютної траєкторії. Початкова швидкість та напрям кидання впливає на час та місие стабілізація pyxy.

Ключові слова: супровідний тригранник, матеріальна точка, похила площина, траєкторія руху

\section{MАРLЕ-МОДЕЛИ ДВИЖЕНИЯ ЧАСТИЦЫ ПО НАКЛОННОЙ ПЛОСКОСТИ, СОВЕРШАЮЩЕЙ ВОЗВРАТНО-ПОСТУПАТЕЛЬНЫЕ КОЛЕБАНИЯ}

\section{А. В. Несвидомин}

Аннотация. Цель исследования - разработка Mapple-модели движения частииы по наклонной плоскости, совершающей возвратно-поступательные колебания. 
Проведен вычислительный эксперимент по исследованию траекторнокинематических свойств движения частицы по наклонной плоскости, которая совершает возвратно-поступательные колебания.

Показано, что для горизонтальной шероховатой плоскости, совершающей возвратно-колебательные перемещения, наиболее быстро стабилизируют абсолютную и относительную траектории частиць по наибольшему коэффициенту трения. Частицы с меньшим коэффициентом трения имеют меньшую амплитуду абсолютной траектории. Начальная скорость $u$ направление бросание влияет на время и место стабилизация движения.

Ключевые слова: сопроводительный трехгранник, материальная точка, наклонная плоскость, траектория движения 